\title{
The Principle of Non-refoulment within the Deportation Procedure, Admission to the Country, Right to Life and the Freedom of Torture and Inhuman or Degrading Treatment or Punishment According to the Turkish Legislation on Temporary Protection Regime
}

\section{ABSTRACT}

This article elaborates on the non-refoulement principle regarding deportation procedure, security, and entry to the country (Turkey) under the 2014 Temporary Protection Regulation, and the 2013 Law on Foreigners and International Protection. According to the document presented by the United Nations Human Rights Office of the High Commissioner “(...) the principle of non-refoulement guarantees that no one should be returned to a country where they would face torture, cruel, inhuman, or degrading treatment or punishment and other irreparable harm. This principle applies to all migrants at all times, irrespective of migration status". The rights of refugees and asylum seekers in mass influx situations are recognized by UNHCR Executive Committee resolutions and general international law. ${ }^{2}$ Thus, it is necessary to analyze the non-refoulement rule as inseparable part of globally accepted principles: the right to life and the freedom from torture and inhuman or degrading treatment or punishment. The article describes the development and violations of the said rule, focusing on the pertinent current Turkish legislation.

\section{KEYWORDS}

non-refoulement, right to life, freedom from torture and inhuman or degrading treatment or punishment, temporary protection

1 Non-refoulement principle. United Nations Human Rights Office of the High Commissioner, https://www.ohchr. org/Documents/Issues/Migration/GlobalCompactMigration/ThePrincipleNon-RefoulementUnderInternationalHumanRightsLaw.pdf. Accessed: 13.09.2020.

2 UNHCR commentary on the draft Directive on Temporary Protection in the Event of a Mass Influx, https://www.refworld.org/docid/437c5ca74.html. Accessed: 13.09.2020; UNHCR guidelines on the application in mass influx situations of the exclusion clauses of Article 1F of the 1951 Convention relating to the Status of Refugees, https://www.refworld.org/pdfid/43f48c0b4.pdf. Accessed: 13.09.2020; The scope of international protection in mass influx EC/1995/ SCP/CRP.3, https:/www.unhcr.org/excom/scip/3ae68cc018/scope-international-protection-mass-influx.html. Accessed: 13.09.2020; Protection of asylum-seekers in situations of large-scale influx, UNHCR 1981, No. 22 (XXXII), https://www.unhcr.org/uk/excom/exconc/3ae68c6e10/protection-asylum-seekers-situations-large-scale-influx.html. Accessed: 13.09.2020. 


\section{The minimum standard of treatment to be provided in the temporary protection regime}

The rights of refugees and asylum seekers in mass influx situations are recognized by the UNHCR Executive Committee resolutions and on grounds of general international law. These rights have also emerged within the UNHCR Executive Committee decisions and the international human rights law. In the Turkish refugee system, the basic refugee rights, described and analyzed in this article, especially those guaranteed by the relevant legislation and the 1982 Constitution as their legal basis, are available to people entitled to a refugee status.

\section{Non-refoulement principle as applied to deportation, security, and entry to the country}

One of the essential elements of temporary protection is ensuring compliance with the country's principles of admission and non-refoulement. Admission to the country causally links to the sovereign domain of the state. In the classical understanding of sovereignty, one of the states' absolute jurisdictions is forming the state's transactions with foreigners: the entry of foreigners into the country, their stay in the country, and their exit, which gives a state almost absolute authority. The principle of non-refoulement is applied in the international conventions on refugees and asylum seekers as well as in the national court cases. The legal status of refugees and asylum-seekers has become a factor limiting the sovereign power of the state.

Turkey is part of the ECHR treaty, UN Convention against Torture and Other Cruel, Inhuman or Degrading Treatment or Punishment, Optional Protocol to the Convention against Torture, European Convention on Extradition, International Covenant on Civil and Political Rights, Optional Protocol to the International Covenant on Civil and Political Rights, the Second Optional Protocol to the International Covenant on Civil and Political Rights, Aiming at the Abolition of the Death Penalty (Protocol), the Convention on the Rights of the Child and UN Convention against Transnational Organized Crime and the Protocols to that. Turkey has regulated the non-refoulement principle under international treaties, agreements, conventions, and protocols. These conventions form a part of domestic law under Article 90 of the Constitution.

Since Turkey's application of non-refoulement principle to the refugee status resembles the European practice sourced from outside Europe, there are no contract obligations. Turkey recognizes the legal status of the refugees as people from European countries. Because of it, when we look at the textual interpretation of the LoFIP, the non-refoulement principle should be applied to the refugees. Thus, there is no obligation to use this rule to people who come outside of Europe. However, by accepting the rules of customary international law, Turkey is obliged to apply the non-refoulement principle to those who come from non-European countries. In short, if Turkey doesn't apply the non-refoulement rule, it will 
violate the customary international law and agreements. For this reason, the principle of non-refoulement directly applies in the Turkish law, and there is no difference due to the geographical limitation in the Geneva Convention.

The principle of non-refoulement will be discussed in connection with admission to the country, which ensures security, and deportation. Since these causally link to the principle of non-refoulement, this principle will also be considered when dealing with the right to life and the right to freedom from torture, cruel and inhuman treatment or punishment.

\section{Non-refoulement procedure and evaluation of deportation according to non-refoulement principle}

The non-refoulement procedure, which is applied to foreigners, means that they have not entered the country. Foreigners are trying to arrive in Turkey illegally or without a valid document. Deportation involves the expulsion process applied to foreigners who have entered the country and stay there. Although the deportation procedure and the principle of non-refoulement may differ from each other, the procedure of non-refoulement also prohibits deportation in some cases. Therefore, it is useful to briefly mention the deportation procedure in connection with the principle of non-refoulement.

Although in the 1982 Turkish Constitution there are no direct regulations related to the entry into the country and deportation of foreigners, it is possible to evaluate and analyze those matters under Article 16 of the Turkish Constitution. One aspect of the deportation process is freedom of travel, which is regulated by Article 23 of the Constitution. Restrictions can be imposed on freedom of travel, which involve situations where a person can go wherever they wish, a person cannot be forced to leave a specific place if they do not wish to, or a person can stay where they are. ${ }^{3}$

According to Article 23 of the Constitution, there is no difference between citizens and foreigners regarding the restrictions related to residence and freedom of travel. According to the last paragraph of Article 23, deportation procedure can only be applied to foreigners, as the citizen cannot be deported. The expulsion or extradition of a foreigner is related to his fundamental rights and freedoms. Another dimension of the deportation procedure is the connection with the freedom and security of a person. This procedure can be considered an exception, regarding foreigners, to the right of freedom and security of persons guaranteed in Article 19 of the Constitution. In Article 19, a person's freedom and security are constitutionally guaranteed, but some exceptional situations are stipulated. The exceptions are causally related to personal safety, as it is possible to expel the foreigner by force, if necessary, during the deportation process. ${ }^{4}$

It is necessary to consider international conventions on deportation, which causally link to fundamental rights and freedoms, and the decisions of the judicial authorities im-

3 R. Aybay, Bir İnsan Hakkı Sorunu Olarak Sınırdışı Edilme, Maltepe Üniversitesi Hukuk Fakültesi Dergisi 2003, No. 2, p. 144.

4 Ibidem, p. 143. 
plementing these conventions. Under Article 2 and the implementation provisions of the LoFIP, the special conditions based on international agreements of which Turkey is part, must be observed. Consequently, the LoFIP will be considered as applied to deportation procedure and other international law treaties, of which Turkey is part. ${ }^{5}$ In the following sections, deportation is discussed from the perspective of personal freedom, security, and freedom of movement. The deportation process, which relates to fundamental rights and freedoms, is explained briefly, but only in terms of the principle of non-refoulement.

The non-refoulement principle is underlying Article 4 of the LoFIP as a fundamental principle, and it applies without any exception. ${ }^{6}$ In Article 63 of the Law, the implementation of the non-refoulement principle was adopted under secondary protection. ${ }^{7}$ According to Article 4 of the Law, "no one within the scope of this law shall be returned to a place where he or she may be subjected to torture, inhuman or degrading punishment or treatment or where his/her life or freedom would be threatened on account of his/her race, religion, nationality, membership of a particular social group or political opinion".

In the first paragraph of Article 54 of the LoFIP, we can find a category of people who can be deported. ${ }^{8}$ According to the second paragraph, if there are indications that the applicant or international protection status holder can be a danger to the countryss security or has been convicted of a crime that poses a threat to the public order, a decision of deportation can be taken. This Article of the LoFIP should be evaluated together with Article 4. The second paragraph of Article 54 indicates the reasons why deportation can be used (national security and public order), and defines the category of people to whom the deportation procedure can be applied (an applicant for international protection or a person who has already been assigned international protection status). However, there is no exception based on the principle of non-refoulement in Article 4. It is possible to deport a person to whom otherwise the principle of non-refoulement would apply, since it is strictly regulated in the LoFIP on grounds of national security and public order. Such persons may never be sent to a place where there are risks mentioned in Article 4.

Article 55 indicates the group of foreigners who cannot be deported even if they fall within the category for which a deportation decision can be made under Article 54. Article $55 \$ 1$-a states that "removal decision shall not be issued in respect of those foreigners listed below regardless of whether they are within the scope of Article 54 when there are serious indications to believe that they shall be subjected to the death penalty, torture, inhuman or degrading treatment or punishment in the country to which they shall be returned to". For

5 N. Ekşi, Yabancılar ve Uluslararası Koruma Kanunu (Tasarısı), İstanbul 2012, p. 123.

6 Ibidem, p. 131.

7 Ibidem, p. 63.

8 LoFIP, Article 54 (2) (Amendment: 3/10/2016-KHK-676/36 Article) "A removal decision may be issued at every stage of international protection proceedings in respect of international protection applicants or international protection beneficiaries who are evaluated as being within the scope of (b: are leaders, members or supporters of a terrorist organization or a benefit-oriented criminal organization), (d: pose a public order or public security or public health threat) and (k: are evaluated as being associated with terrorist organizations which have been defined by international institutions and organizations) subparagraphs of the first paragraph of this Article". 
foreigners who will benefit from this Article, evaluations are made individually. ${ }^{9}$ This regulation states further that the person cannot return to the place where these risks will occur by the prohibition of return stipulated in Article 4 . However, within the scope of Article 4, it is also regulated that a person cannot be sent to a place where his/her life or freedom will be threatened due to his/her race, religion, nationality, membership of a specific social group, or political ideas. Article 4 defines these persons' situation, given Article 54 and the exemption in Article 55. According to Article 55, "when there are serious indications to believe that they shall be subject to the death penalty, torture, inhuman or degrading treatment or punishment in the country to which they shall be returned to", the absoluteness of applying this principle is preserved.

The deportation decision will not be taken for the country for which the deportation would harm the absoluteness of Article 4 . When the country to which a person would be deported is "a place where he or she may be subject to torture, inhuman or degrading punishment or treatment or, where his/her life or freedom would be threatened on account of his/her race, religion, nationality, membership of a particular social group or political opinion", and due to that fact it is not regulated in the deportation decision, the person will not be sent to that place under the absolute rule of Article 4. The persons for whom a deportation decision may be taken, will not be sent to places where their lives or freedom will be threatened because of their race, religion, nationality, membership of a specific social group, or political ideas.

While Article 4 is evaluated together with Article 55, not making an exception according to the non-refoulement principle under Article 4 seems to cause controversy. According to the LoFIP draft, in the second paragraph of Article 4, which regulated the principle of non-refoulement, it was stated that the exception in the second paragraph of Article 33 of the Geneva Convention ${ }^{10}$ is reserved. However, the draft was enacted after removing this exception.

The exclusion of this exception from the text was accepted in the Sub-Commission report since it would not make sense to have Article 3 of the European Convention on Human Rights - the Prohibition of Torture in the context of the absolute validity of the Article. ${ }^{11}$ At this point, the situation regarding the absolute nature of the prohibition of torture is understandable. There does not appear to be a satisfactory justification for lifting the exception of non-refoulement for the danger of persecution. ${ }^{12}$ There are criticisms that the regulation

9 N. Ekşi, op. cit, p. 123.

10 Article 33 prohibition of expulsion or return ("refoulement") "1. No Contracting State shall expel or return ("refouler") a refugee in any manner whatsoever to the frontiers of territories where his life or freedom would be threatened based on his race, religion, nationality, membership of a particular social group or political opinion. 2. The benefit of the present provision may not, however, be claimed by a refugee whom there are reasonable grounds for regarding as a danger to the security of the country in which he is, or who, having been convicted by a final judgment of a particularly serious crime, constitutes a danger to the community of that country". https://www.unhcr.org/3b66c2aa10. Accessed: 13.09.2020.

11 The Grand National Assembly of Turkey, Internal Affairs Commission, Sub-Commission Report Rule No. 1/169 (18.06.2012), pp. 236-245, https://www.tbmm.gov.tr/komisyon/insanhaklari/belge/24_donem_3_yasama_yili_faaliyet_raporu.pdf. Accessed: 13.09.2020.

12 N. Öztürk, Mültecinin Hukuki Statüsünün Belirlenmesi, 2015, p. 417. 
on the principle of non-refoulement in Article 4 does not include any exceptions contrary to the Geneva Convention, which can be interpreted as the detriment of the situation of refugees who need international protection. The fear of persecution is closely related to the determination of the individual's status and non-refoulement to a place where his/her life or freedom is threatened. Furthermore, considering these two equal with each other, Article 4 is only for the prohibition of torture due to safety concerns. There is a risk that it will apply as such.

\section{Non-refoulement principle and deportation procedure for temporary protectors}

The deportation of those under temporary protection is not included in the Temporary Protection Regulation, where the principle of non-refoulement is adopted similarly as in the LoFIP. According to Article 6 of the said Regulation, titled "Non-refoulement", "no one within the scope of this Regulation shall return to a place where he or she may be subjected to torture, inhuman or degrading punishment or treatment or where his/her life or freedom would be threatened on account of his/her race, religion, nationality, membership of a particular social group or political opinion". Even if Article 6 of the Regulation did not exist, the provisions and Article 4 of the LoFIP would constitute an adequate legal basis for the prohibition of returning those under temporary protection.

Those who are considered dangerous for the state, public security or public order can have their temporary protection status time shortened and undergo deportation. The decision of deportation of the temporarily protected person is taken in compliance with the principle of non-refoulement.

According to Ekşi (2012), the Regulation should contain a provision as to whether the temporarily protected persons would be deported under Article $54 \$ 2$ of the LoFIP. The Regulation states that the protected persons do not have an international protection status and asylum application opportunities, which means that they do not have the "applicant" qualification. Therefore, it is clear that, despite the textual interpretation of the LoFIP, the temporarily protected persons are not included in the second paragraph's scope, which constitutes an exception to the first paragraph. Foreigners to be deported are specified. The application of the first paragraph of Article $54^{13}$ of the LoFIP should take into account those

13 Article 54: “(1) A removal decision shall be issued in respect of those foreigners listed below who/whose: a) are deemed to be removed pursuant to Article 559 of the Turkish Penal Code № 5237; b) are leaders, members or supporters of a terrorist organization or a benefit-oriented criminal organization; c) submit untrue information and false documents during the entry, visa, and residence permit actions; ç) made their living from illegitimate means during their stay in Turkey; d) pose a public order or public security or public health threat; e) has overstayed their visa or the visa exemption period for more than ten days or, whose visas are canceled; f) residence permits are canceled; g) overstayed the expiry date of the duration of their residence permit for more than ten days without an acceptable reason; $\breve{g}$ ) are determined to be working without a work permit; h) breach the terms and conditions for legal entry into or exit from Turkey; $\imath$ ) is determined to have entered into Turkey despite an entry ban to Turkey; i) international protection claim has been refused; are excluded from international protection; the application is considered inadmissible; has withdrawn the application or the application is considered withdrawn; international protection status has ended or has 
under temporary protection. As mentioned above, the Temporary Protection Regulation stipulates different status than the general rules of the LoFIP. According to the Regulation part titled "Application of the temporary protection right", Articles 5, 6, and 7 of the LoFIP cannot be interpreted and applied in a way that prevents the foreigner's request for temporary protection. Article 5 states that "Entry into and exit from Turkey shall be through the border gates with a valid passport or travel document". According to Article 5 of the Regulation, foreigners included in the Regulation's scope cannot be punished for illegal entry into and stay in the country. This Article regulates also the control of documents. Article 7 describes the situation of foreigners who shall refuse to enter Turkey. The Regulation should consider evaluation of the reasons for expulsion of the temporarily protected persons, specified in the first paragraph of Article 54 .

\section{Evaluation of the non-refoulement principle as applied to the entry into the country}

Under the principle of non-refoulement, the state must allow entry into their territory when people, due to a hypothetical prosecution or war, want to find protection abroad. ${ }^{14}$ Turkey, before the LoFIP, adopted the temporary protection principle. By conducting the open border policy, which is based on the principle of non-refoulement, Turkey helps to register and replace the oncoming refugees in the refugee camps. ${ }^{15}$ Turkish authorities are using the open border policy towards the Syrian refugees, but sometimes it may cause legal problems. For instance, the Turkish border security service may refuse the entry into the country due to lack of a passport. As a results of such incidents, the Turkish border security service became a victim of quasi-military attacks by Syrians. That was why some border crossing points in Suruç, Akçakale, Ceylanpınar, and Nusaybin had been closed to Syrians. This situation shows that the temporary protection regime is one of Turkey's open border policy principles. Due to the open-border policy, Turkey has faced many dangerous incidents and situations on the country's borders. Thus, the refugees who escape from Syria might be dangerous for the state policy and security. According to Amnesty International's reports, Turkey was not ready to welcome many thousands of refugees and provide them necessary medical nad humanitarian aid. ${ }^{16}$

been canceled, provided that pursuant to the other provisions set out in this law they no longer have the right of stay in Turkey after the final decision. j) fail to leave Turkey within ten days in cases where their residence permit renewal application has been refused. k) (Annex: 3/10/2016-KHK-676/36 Article) are evaluated as being associated with terrorist organizations that have been defined by international institutions and organizations".

14 Amnesty International, Hayatta Kalma Mücadelesi: Türkiye'deki Suriye’den Gelen Mülteciler, https://www.amnesty.org/ en/documents/EUR44/017/2014/tr/, p. 9. Accessed: 13.09.2020.

15 S. Özden, Syrian refugees in Turkey: Migration Policy Centre, 2013, http://migrationpolicycentre.eu/docs/MPCRR-2013-05.pdf, p. 5. Accessed: 13.09.2020.

16 Amnesty International, op. cit., p. 10. 
The deportation of 600 people from Akçakale is one example of the violation of the nonrefoulement principle and the open-door policy. ${ }^{17}$

The Akçakale customs gate was closed after the incident of May 2, 2013, where one police officer died and five people were injured. After this incident, the investigation has started, and the Turkish authorities discovered that all the refugees were allowed to cross the Turkish border without a passport or any document by paying 100 TL per person to the Turkish customs officers. $^{18}$

There are many other examples of the Turkish crossing border points. The entry into Turkey without a passport from Syria and other neighboring countries was allowed due to the open border policy. For example, Turkey has established the Yumurtalık border crossings to facilitate the asylum seekers' entry from Kobane. ${ }^{19}$ Due to the tremendous concentration of the radical Islamist organizations in the Turkish-Syrian border area, since July 2013 Turkey has closed its borders to everyone except those with urgent medical needs.

According to the Directive of the Ministry of Interior of March 12, 2012, the Palestinians who cross the Turkish border from the Syrian side will be able to apply for asylum status on the same conditions as the Syrian refugees. Thus, these people's inability to enter the country through official border crossing has been another problematic admission situation. Palestinian refugees would be able to apply for temporary protection without any further visa application. In some cases, visas were not requested from Syrians but were requested from Palestinians. Under the UNHCR reports, due to a lack of visa application, the Palestinians who were coming to Turkey from Syrian borders would be sent to a safe third country. However, there are no reports of Palestinians sent to Syria. ${ }^{20}$

According to the non-refoulement principle and the open-door policy, Turkey provides a sufficient number of safe border crossing point facilities for the Syrian refugees, who can enter Turkey without valid travel documents. ${ }^{21}$

\section{Right to life}

The right to life is a fundamental right. All other rights derive from it and depend on it. This right, which includes the right not to be killed by public authorities and to be protected by

17600 Syrians have been deported, DHA, http://www.dha.com.tr/son-haber-600-suriyeli-sinir-disi-edildi_447808.html. Accessed: 13.09.2020.

18 T. Kılıç, Suriyeli Mülteciler, “Zaman” 14.05.2013, http://www.zaman.com.tr/yorum_suriyeli-multeciler_2089308.html. Accessed: 13.09.20.

19 Amnesty International, op. cit., pp. 10-11.

20 UNHCR, Frequently Asked Questions: Syrian Refugees in Turkey, http://www.unhcr.org.tr/uploads/root/faqenglish. pdf, November 2013. Accessed: 13.09.2020

21 Amnesty International, op. cit., p. 19. 
public authorities against dangers and risks to life, can be briefly expressed as the right not to be killed. ${ }^{22}$

Undoubtedly, one of the main reasons the state applies the principle of non-refoulement to the influx of refugees is that these people's lives are in danger in their countries of origin. The most fundamental right is in need of protection in the countries where the masses are fleeing from - the right to life.

According to Article 2 of the ECHR, everyone has the right to life protected by law. The right to life regulated in Article 2 is not absolute, and this Article provides the possibility of putting restriction on this right. The right to life is generally discussed in the legal literature with mentioning Article 2 of the ECHR and the ECHR decisions. In this section I discus the violation of the right to life caused by non-refoulement principle as a significant element of the policy towards the mass influx of refugees. ${ }^{23}$

When we look at the outcome of the Syrian crisis and the incidents with Turkish border points officers, the "pushing back policy" applied towards the Syrian refugees becomes problematic. These practices force these people to use irregular entry points. ${ }^{24}$ Some such cases were reported in the middle of the Turkish-Syrian border. During these raids, some people died by stepping on a mine. ${ }^{25}$ UNHCR officials warned the Turkish authorities of the risks faced by Syrians making irregular crossings to the country. ${ }^{26}$

According to Amnesty International, between December 2013 and August 2014, there were 17 death incidents caused by the use of firearms. These fatalities occurred during border crossings made by irregular routes. Investigations were launched in only two of these cases. ${ }^{27}$ On the night from May 18 to May 19, 2013, 14-year-old Ali Özdemir was shot in the head as he approached the Kizlltepe border. The boy lost both eyes. A criminal complaint was made regarding the incident. Süleyman Ahmed Halef was shot dead by a privateer while trying to enter the border on December $29,2013{ }^{28}$ The criminal investigation into

22 Cengiz Topel Çiftçioğlu, Yaşam Hakkı, “TBB Newspaper” 2012, No. 103, p. 138; M. Sezgin Tanrıkulu, IHAM Kararlarında ve Türk Hukukunda Yaşama Hakkı, “TBB Newspaper” 2006, No. 66, pp. 51-52; E. Ergül, Bireysel Başvuru ve Uygulaması, Ankara 2012, p. 145.

23 When people have successfully crossed the Turkish border and there is a deportation decision towards them, this policy is called "throwing back." When the Turkish authority does not permit to enter Tukey in the border points, this policy is called "pushing back.” Kılıç writes: “(...) without any kind of individualized applications of persons who have entered the country's borders, without being heard, without any legal mechanism, on a completely unlawful ground, when there is no need to make any official report of incoming people by the law enforcement officers, the decision of deportation or expulsion is applying in the way that it is doing by force and in the manner that is against human dignity, and often in a life-threatening way”. Kılıç, T., Sintrlardaki Mülteciler ve Ege Denizi'ndeki İhlaller, "Taraf” 27.06.2014, http://arsiv.taraf.com.tr/haber-sinirlardaki-multeciler-ve-ege-denizindeki-ihlaller-157816. Accessed: 13.09.2020.

24 Amnesty International, op. cit., p. 13; UNHCR, Frequently Asked Questions..., op. cit. According to the AFAD report, 43 percent of Syrians were living in camps. Those living outside the camps and the percentage of those who unofficially crossed the Turkish border was around 50. AFAD, Türkiye’ deki Suriyeli Sı̆̆ınmacılar, 2013 Saha Araştırması Sonuçları, https://afad.gov.tr/Dokuman/TR/602013123015491-syrian-refugees-in-turkey-2013_baski_30.12.2013_tr.pdf, p. 22. Accessed: 13.09.2020.

25 Amnesty International, op. cit., p. 13. Headline related to the death of 3 Syrian refugees crossing one of the unofficial Turkish border points: https://www.ntv.com.tr/arsiv/id/25378188. Accessed: 13.09.2020.

26 UNHCR, Frequently Asked Questions..., op. cit.

27 Amnesty International, op. cit., p. 15.

28 Ibidem, pp. 15-16. 
the incident is ongoing. One of the fatal victims of the non-refoulement principle violation is Mustafa Şems el-Din Haj Ismail. ${ }^{29} \mathrm{He}$ was trying to cross the Turkish-Syrian border illegally, and was detained by a border official. Mustafa Şems el-Din Haj Ismail's dead body laid on a clamp wire mesh between Turkey and Syria. ${ }^{30}$

The "pushing back policy" caused many unjustified uses of firearms with fatal outcome, unlawful use of force, and abusive activities by the Turkey's border guards. ${ }^{31}$ According to the 10-page Amnesty International report, submitted to the Ministry of Interior and the Directorate General of Migration Management, 17 unjustified uses of firearms had fatal outcomes. However, Amnesty International did not receive any response from the authorities on this matter. ${ }^{32}$

Frequent violations of the right to life in cases of deportation or keeping people away from the border are vital for those trying to enter the country both regularly and irregularly in mass influx. In this regard, the ECHR's Petros Kakoulli v. Turkey ${ }^{33}$ case became a signature for the Syrian refugees. In this case, the applicant alleges that Kakoulli crossed the border, and subsequently the Turkish soldiers started to warn him to stop. However, he did not, so the soldiers fired two shots, despite Kakoulli was standing with his hands on his head, and Kakoulli found death with the third shot. According to the ECHR, the agreements on the form of the rules, security measures, border forces, and regulations in the national legislation are related to the allegation of violation of the right to life and the allegation of violation of Articles 8 and 14 of the ECHR. In this context, lethal intervention by border guards against civilians in terms of their duties is unacceptable. Stating that Kakoulli could be stopped and rendered harmless without lethal intervention, the Court found that the soldiers' intervention was contrary to the principle of proportionality. The ECHR, which found that there was not enough investigation into the death, ruled that the right to life was violated. The state's obligation to protect the foreigners' rights and freedoms does not change if a mass influx of refugees approaches a country border. So, for those who want to cross the Turkish border and apply for international protection or temporary protection based on the international law and the ECHR decision following from the right to life, the Petros Kakoulli v. Turkey case is a significant milestone. In response to a request and a proposal from Amnesty International, Turkish authorities should investigate more effectively and according to the international standards all cases when the Turkish border oficials overuse their force by exerting disproportional violence. ${ }^{34}$ Only in this way will they have fulfilled all its obligations concerning the right to life in Turkey.

\footnotetext{
29 Ibidem.

30 Ibidem, p. 17.

31 Ibidem, p. 9.

32 Ibidem, pp. 10, 14.

33 ECHR, Kakoulli v. Turkey (No.38595/97), 22.10.2005, http://hudoc.echr.coe.int/eng?i=001-71208. Accessed: 13.09.2020.

34 Basic principles on the use of force and firearms by law enforcement officials. Adopted by the Eighth United Nations Congress on the Prevention of Crime and the Treatment of Offenders, Havana, Cuba, August 27 to September 7, 1990, https://www.ohchr.org/en/professionalinterest/pages/useofforceandfirearms.aspx. Accessed: 13.09.2020.
} 


\section{Freedom from torture and inhuman or degrading treatment or punishment}

According to the UNHCR Executive Committee, those who come in massive influxes should be treated as people whose tragic escape requires unique understanding and sympathy. They should not be subject to cruel, inhuman or degrading treatment simply because they entered the country illegally or for any other reason. ${ }^{35}$ This obligation is an absolute necessity for the prohibition of torture to be an ius cogens in the international law rule. The most significant example of inhuman treatment of those Syrian refugees who seek temporary protection was detaining 300 people in a sports hall. In this case, the inaccessibility of health services for many people with health problems caused by the unsatisfactory conditions in the sports hall was undoubtedly an essential example of inhuman or degrading punishment or treatment by the Turkish authorities. ${ }^{36}$ Under Article 3 of the ECHR Agreement ${ }^{37}$ and Article 17 of the Turkish Constitution, those activities towards refugees were against the law. In a report made after the interviews with the detained Syrian refugees, the Amnesty International stated that the detainees were threatened with indefinite detention in Turkey if they did not agree to return to Syria and not enter again. Without any doubt, this type of threat was a violation of the principle of non-refoulement. ${ }^{38}$

In its report, which included the timeframe between November 2013 and August 2014, Amnesty International stated that 31 people were killed in 19 different cases because of using illegal border crossing points. In these cases, violence was usually involved using punches, kicks, sticks, and gun grips. According to another Syrian refugee testimony, there were allegations of leaving people naked, relieving themselves on the floor. Those who were beaten and their relatives were sent back to Syria. ${ }^{39}$ The Amnesty International has given a few other examples. They include the illegal border crossing by Muhammed and two young people accompanying him in May 2014, the border crossing by Lokman (not real name) on the night from August 3 to August 4, 2014 ${ }^{40}$, and a border crossing by 60 -year-old Mohammad Ali and his daughter Hervin (not real name) in June $2014^{41}$. In all those cases, the refugees were beaten by the Turkish border authorities.

All these facts of torture, inhuman or degrading treatment or punishment should be investigated in the criminal proceedings carried out according to the principle of formal,

35 Executive Committee, Conclusion No. 22 (XXXII), UNHCR 1981, Conclusions adopted by the Executive Committee on International Protection of Refugees, 2009, http://www.refworld.org/pdfid/4b28bf1f2.pdf. Accessed: 13.09.2020.

36 Amnesty International, op. cit., pp. 11-12.

37 Article 3 "No one shall be subjected to torture or inhuman or degrading treatment or punishment". Convention for the Protection of Human Rights and Fundamental Freedoms, https://www.echr.coe.int/Documents/Convention_ENG. pdf. Accessed: 13.09.2020.

38 Amnesty International, op. cit., p. 11.

39 Ibidem, p. 16.

40 Ibidem, p. 18.

41 Ibidem. 
distinctive effectiveness due to international obligations and measures. ${ }^{42}$ Besides, necessary measures should be taken to prevent such actions by the border authorities in the future.

The ECHR conducted numerous lawsuits and gave verdicts against Turkey for violation of human rights. Those cases show how important are court decisions taken under Article 3 of the ECHR Convention on individual asylum situations and temporary protection. Temporarily protected persons should be treated according to the regulations of Article 17 of the Turkish Constitution, Article 3 of the ECHR, and other conventions of which Turkey is part. During the deportation and detention, it is essential to give the refugees information $\mathrm{ab}$ out the places where they are kept. At this point, it is useful to remember the provisional cautionary decision of the Constitutional Court mentioned in the "Right to life" section above.

\section{Summary}

It is impossible to analyze the non-refoulement principle within temporary protection legal construction without the correct approach towards the country's deportation and entry to the country system. Admission to the country is one of the most relevant domains of sovereign country status. After World War II, the national law became more unified with international legislation as a control and balance leverage. Consequently, the refugees and asylum seekers' legal status has been starting to limit the country's sovereignty.

Turkey became part of bilateral international and European conventions and treaties related to the non-refoulement rule.

Due to the Turkish geographical reservation of the 1951 Refugee Convection, Turkey is liable for recognizing refugee status only of those entering Turkey from a European country. Simultaneously, by not applying the non-refoulement principle to non-European refugees, Turkey violates the acquis communautaire.

It is necessary to evaluate the deportation procedure under Article 4 (non-refoulement) of the LoFIP because while Article 4 applies without any exception the deportation process can be stopped (Article 55).

Since there is no term related to deportation in the Temporary Protection Regulation, Turkish lawmakers per analogia use the LoFiP legal construction towards temporary protection.

The admission to the country and the open border policy cause a legal problem. The fact that many Syrian refugees came to Turkey without a valid passport or any passport at all, caused some military incidents in the Turkish border checkpoints, unfamous deportation cases (human smuggling), and inhuman behaviors from both sides.

The right to life is a fundament for the non-refoulement principle because a welcoming country guarantees not to send the person back to the place where his/her life is in danger. Unfortunately, the right to life rule is not absolute and may be put under restriction, 
to mention the "pushing back policy" applied towards the Syrian refugees by the Turkish authorithies.

The temporary protected should not be subject to cruel, inhuman or degrading treatment simply because they entered the country illegally or for any other reason. It is an absolute necessity for the prohibition of torture to be an ius cogens of the international law rule.

\section{Literature}

Aybay R., Bir İnsan Hakkı Sorunu Olarak Sınırdışı Edilme, Maltepe Üniversitesi Hukuk Fakültesi Dergisi, No. 2, Year 2003.

Çiftçioğlu C.T., Yaşam Hakkı, TBB Newspaper 2012, No. 103.

Ekşi N., Yabancılar ve Uluslararası Koruma Kanunu (Tasarısı), İstanbul 2012.

Ergül E., Bireysel Başvuru ve Uygulaması, Ankara 2012.

Öztürk N., Mültecinin Hukuki Statüsünün Belirlenmesi, Seçkin Yayınları 2015.

Tanrıkulu M.S., IHAM Kararlarında ve Türk Hukukunda Yaşama Hakkı, TBB Newspaper 2006, No. 66 .

\section{Legislative sources}

Basic principles on the use of force and firearms by law enforcement officials. Adopted by the Eighth United Nations Congress on the Prevention of Crime and the Treatment of Offenders, Havana, Cuba, August 27 to September 7, 1990.

Convention for the Protection of Human Rights and Fundamental Freedoms.

Executive Committee, Conclusion No. 22 (XXXII), UNHCR 1981, Conclusions adopted by the Executive Committee on International Protection of Refugees, 2009.

Law on Foreigners and International Protection No. 6458 of 2013.

Non-refoulement principle. United Nations Human Rights Office of the High Commissioner.

Protection of asylum-seekers in situations of large-scale influx, UNHCR 1981, No. 22 (XXXII).

The Grand National Assembly of Turkey, Internal Affairs Commission, Sub-Commission Report Rule No. 1/169 (18/06/2012).

The scope of international protection in mass influx EC/1995/SCP/CRP.3.

The 1951 Refugee Convention.

UNHCR commentary on the draft Directive on Temporary Protection in the Event of a Mass Influx.

UNHCR guidelines on the application in mass influx situations of the exclusion clauses of Article $1 \mathrm{~F}$ of the 1951 Convention relating to the Status of Refugees.

\section{Judicial decision}

ECHR, Kakoulli v. Turkey (No. 38595/97), 22.10.2005.

\section{Websites}

AFAD, Türkiye’ deki Suriyeli Sı ̆̆ınmacılar, 2013 Saha Araştırması Sonuçları, https://afad.gov.tr/ Dokuman/TR/602013123015491-syrian-refugees-in-turkey-2013_baski_30.12.2013_tr.pdf. Accessed 13.09.2020. 
Amnesty International, Hayatta Kalma Mücadelesi: Türkiye'deki Suriye'den Gelen Mülteciler, https://www.amnesty.org/en/documents/EUR44/017/2014/tr/. Accessed 13.09.2020.

DHA, http://www.dha.com.tr/son-haber-600-suriyeli-sinir-disi-edildi_447808.html. Accessed 13.09.2020.

Kılıç T., Sınırlardaki Mülteciler ve Ege Denizi’ndeki İhlaller, “Taraf” 27.06. 2014, http://arsiv.taraf. com.tr/haber-sinirlardaki-multeciler-ve-ege-denizindeki-ihlaller-157816. Accessed 13.09.2020.

Kılıç T., Suriyeli Mülteciler, “Zaman” 14.05.2013, http://www.zaman.com.tr/yorum_suriyeli-multeciler_2089308.html. Accessed 13.09.2020.

NTV (news), https://www.ntv.com.tr/arsiv/id/25378188. Accessed 13.09.2020.

Özden Ş., Syrian refugees in Turkey: Migration Policy Centre, 2013, http://migrationpolicycentre.eu/ docs/MPC-RR-2013-05.pdf. Accessed 13.09.2020.

The Grand National Assembly of Turkey, Internal Affairs Commission, Sub-Commission Report Rule No. 1/169 (18/06/2012), https://www.tbmm.gov.tr/komisyon/insanhaklari/belge/24_donem_3_yasama_yili_faaliyet_raporu.pdf. Accessed 13.09.2020.

UNHCR, Frequently Asked Questions: Syrian Refugees in Turkey, http://www.unhcr.org.tr/uploads/ root/faqenglish.pdf, November 2013. Accessed 13.09.2020.

CITATION

J. Kuruçaylığlu, The Principle of Non-refoulment within the Deportation Procedure, Admission to the Country, Right to Life and the Freedom of Torture and Inhuman or Degrading Treatment or Punishment According to the Turkish Legislation on Temporary Protection Regime, Studia Administracyjne 2(14)/2021, 31-44, DOI: 10.18276/sa.2021.14-03. 